\title{
Effect of chronic T-2 toxin exposure in rabbit bucks, determination of the No Observed Adverse Effect Level (NOAEL)
}

\author{
Melinda Kovács ${ }^{\mathrm{a}, \mathrm{b}, *}$, Gábor Tornyos ${ }^{\mathrm{a}}$, Zsolt Matics ${ }^{\mathrm{b}}$, Miklós Mézes ${ }^{\mathrm{c}}$, Krisztián Balogh ${ }^{\mathrm{c}}$, \\ Veronika Rajli ${ }^{\mathrm{a}}$, Zsófia Bloch-Bodnár ${ }^{\mathrm{a}}$, Miklós Rusvai ${ }^{\mathrm{d}}$, Míra Mándoki ${ }^{\mathrm{d}}$, Sándor Cseh ${ }^{\mathrm{d}}$ \\ a Kaposvár University Faculty of Animal Science, Guba S. 40, 7400 Kaposvár, Hungary \\ b MTA-KE Mycotoxins in the Food Chain Research Group, Guba S. 40, 7400 Kaposvár, Hungary \\ c SZIU Faculty of Agricultural and Environmental Sciences, Páter K. 1, 2001 Gödöllő, Hungary \\ d SZIU Faculty of Veterinary Science, István 2, 1078 Budapest, Hungary
}

\section{A R T I C L E I N F O}

\section{Article history:}

Received 8 October 2012

Received in revised form 11 January 2013

Accepted 15 January 2013

Available online 23 January 2013

\section{Keywords:}

T-2 toxin

Rabbit

Sperm quality

No Observed Adverse Effect Level (NOAEL)

\begin{abstract}
A B S T R A C T
T-2 toxin (T-2) was administered to adult Pannon White ( $n=10 /$ group) male rabbits for 65 days, first in a suspension by gavage $(0.05,0.1$ or $0.2 \mathrm{mg} / \mathrm{animal} / \mathrm{day})$, and secondly mixed into the feed ( 0.33 and $0.66 \mathrm{mg} / \mathrm{kg}$ feed). In the first experiment $0.1 \mathrm{mg} \mathrm{T}-2$ exposure resulted in temporary decrease in feed intake, slower increase in the gonadotropin-releasing hormone $(\mathrm{GnRH})$ induced testosterone synthesis, slight centrolobular infiltration in the liver and a slight hyperplasia of the Leydig cells. In addition to the temporary feed refusal effect, $0.2 \mathrm{mg}$ T-2 caused a temporary decrease in plasma albumin and urea concentrations, lesser glutathione peroxidase (GPX) activity in the seminal plasma, a greater (by $320 \%$ ) ratio of spermatozoa with cytoplasmic droplets, slower increase in the GnRH-induced testosterone synthesis, centrolobular infiltration in the liver, slightly hyperaemic testes and increased proliferative activity of the Leydig cells. The two smaller doses applied in feed 0.33 and $0.66 \mathrm{mg} / \mathrm{kg}$ ) did not cause any significant adverse effect, and no feed refusal was observed. According to these results the No Observed Adverse Effect Level (NOAEL) of T-2 for adult rabbit males was found to be $<0.1 \mathrm{mg} /$ animal/day $(<0.02 \mathrm{mg} / \mathrm{kg} \mathrm{b} . w . /$ day $)$.
\end{abstract}

(c) 2013 Elsevier B.V. All rights reserved.

\section{Introduction}

Secondary toxic metabolites of Fusarium molds (fusariotoxins) are frequent contaminants in cereal and other plant products (Scott, 1990). Fusarium molds predominantly produce two types of mycotoxins: the non-estrogenic trichothecenes and the mycoestrogens including zearalenone and its zearalenol metabolites. T2 toxin (T-2) is the most acute toxic compound among trichothecenes: it inhibits protein, DNA and RNA synthesis (therefore injuring organs with rapidly dividing cell

\footnotetext{
* Corresponding author at: Kaposvár University, Guba S. Street 40, 7400 Kaposvár, Hungary. Tel.: +36 82505800; fax: +36 82505970.

E-mail address: kovacs.melinda@ke.hu (M. Kovács).
}

populations), alters cellular membrane functions, stimulates lipid peroxidation, is cytotoxic and immunotoxic and induces apoptosis (SCF, 2001).

The effect of T-2 on reproduction has been widely studied in female animals, while knowledge about its effect on spermatozoa, testosterone production, i.e. reproduction processes in males is limited. T-2 was found to inhibit testosterone secretion in gerbil testicular interstitial cells in vitro (WHO, 2001). Yang et al. (2010) investigated the effects of T-2 on semen quality, fertility and serum testosterone concentration in mice after intra-peritoneal injection of $0,5,10$ and $15 \mathrm{mg} / \mathrm{kg}$ b.w. T-2 on 7 consecutive days. A dose-dependent reduction of sperm count in the testes and epididymidis and increase in the number of abnormal spermatozoa occurred. Semen quality of bulls was also impaired after a treatment with a small 
dose of T-2 and HT-2 toxin (117.5 $\mu \mathrm{g}$ T-2/day and $1425 \mu \mathrm{g}$ HT-2/day) for about 14 weeks, with poor progressive motility and poor morphology of spermatozoa being observed. The effect persisted until 5 month after withdrawal of the moldy hay (Alm et al., 2002). The subsequent effect of T-2 applied to rabbits in larger doses $(4 \mathrm{mg} /$ animal/day for 3 days) was manifested by a decreased sperm motility, increased number of spermatozoa with morphological abnormalities, decrease in concentration of citric acid in seminal plasma, and decrease in testosterone concentration after 48 days following a 3-day long sub-chronic toxicosis (Kovács et al., 2011). Interaction of T-2 with reproduction in rabbits was reported by WHO (2001), but the studies were criticized due to their poor description. However, in addition to taking reproductive disorders into consideration from an animal production perspective, studying effects in rabbits can be of special interest, as this animal species is known to be a good model of human reproductive toxicology. Using the rabbit in reproductive toxicological studies has several advantages, e.g. the male rabbit is the smallest, least expensive animal that can be ejaculated with an artificial vagina, permitting longitudinal evaluation of semen characteristics (Morton, 1988). The recognition of the importance of sperm morphology measurements in men exposed to various agents, and the repeatability of morphometric measurements of rabbit sperm add to the value of the male rabbit as an especially useful model (Foote and Carney, 2000).

In several studies, it has been concluded that the major factors with regard to male subfertility or infertility are being sought among environmental and industrial chemicals, antibiotics and cytotoxic drugs, heavy metals, and dietary toxins, e.g. mycotoxins. People all over the world can be exposed to prolonged intake of mycotoxins in small doses. According to the most recent overview (Van der Fels-Klerx and Stratakou, 2010) on the occurrence of T-2 and HT-2 toxin (HT-2) in grain and grain-based commodities in Europe, the incidence and concentrations of these toxins were the greatest in oats through 2007 with reduced amounts being detected in recent years. The contamination of barley and maize except in some incidental cases was little, wheat, durum wheat, triticale and rye were not susceptible to T-2/HT-2 contamination. Of the cereal derived food products, oat products were contaminated to the greatest extent. Because the consumption of wheat products in Europe exceeds that oat derived products, even the lesser contamination of wheat may also be significant in case of longer exposure. There are currently no EC limits for T-2 and HT-2 and no recent risk assessments on these grains in the European community, mainly because of a lack of a complete up-to-date overview of the occurrence of these two toxins.

To determine the No Observed Adverse Effect Level (NOAEL) and by this providing data for the calculation of the tolerable limit levels of T-2 in bucks, two experiments were conducted, in which the toxin was administered during 65 days in small doses, first in a suspension by gavage (Experiment 1 ), and secondly mixed into the feed (Experiment 2).

\section{Materials and methods}

\subsection{Animals, housing and treatments}

Pannon White ( $n=10 /$ group) male rabbits (weight: $4050-4500 \mathrm{~g}$, age: 9 month) trained to ejaculate into an artificial vagina were used in the experiments. Rabbits were individually housed in wire mesh cages $(42 \mathrm{~cm} \times 50 \mathrm{~cm})$ in a closed building, with 16 light hours per day. Average temperature ranged from 16 to $18^{\circ} \mathrm{C}$ and the farm had overpressure ventilation. The animals received a commercial diet containing $10.3 \mathrm{MJ}$ digestible energy (DE)/kg, $15.5 \%$ crude protein, $4.0 \%$ crude fat and $14.7 \%$ crude fiber, ad libitum, and had free access to drinking water from weight-valve selfdrinkers.

T-2 was produced experimentally on corn grits by Fusarium sporotrichioides strain NRRL 3299, as described by Fodor et al. (2006). In the first experiment T-2 was extracted and purified according to the methodology described previously (Kovács et al., 2011). Treated animals received $0.05,0.1$ or $0.2 \mathrm{mg} /$ animal/day T-2 toxin, while control animals received toxin free suspension by gavage for 65 days. The toxin containing suspension was prepared by dissolving the crystallized T-2 in ethanol, and thereafter diluted with distilled water to get ethanol concentration $\leq 2 \%$.

Taking the results of the first experiment into consideration, in the second experiment the fungal culture was mixed to the diet of the rabbits so, that the T-2 concentrations corresponded to the two smaller doses of the first experiment, i.e. 0.33 and $0.66 \mathrm{mg} / \mathrm{kg}$ complete feed. Control animals received a diet with no detectable T-2 toxin content.

Individual feed consumption was recorded daily. The body weight was measured weekly. Animal health status was checked every day.

In both experiments, semen was collected with an artificial vagina after 65 days of toxin exposure. Subsequently, the GnRH-challenge test wasconducted. The animals were treated with $0.2 \mathrm{ml}$ GnRH-analog i.m. (Receptal, Intervet, The Netherlands). The concentrations of testosterone were determined from blood samples collected from the marginal ear vein just prior to GnRH-analog injection $(0 \mathrm{~min})$ and thereafter in the 25th, 50th, 75th, 90th and 115th minute.

Blood samples were taken at the beginning (Day 0 ), on the 30th day and at the end (Day 65) of the experiment to determine certain parameters of clinical chemistry and the antioxidant status. At the end of the experiment animals were euthanized by intravenous barbiturate overdose, exsanguinated, necropsied, the weight of liver, spleen, kidneys and testes was measured, the relative weight (expressed as \% of body weight) calculated, and the testes were subjected to histo-pathological examination.

The experimental protocol was authorized by the Food Chain Safety and Animal Health Directorate of the Somogy County Agricultural Office, under permission number 23.1/02322/007/2008. 
Table 1

Effect of T-2 toxin administered by daily gavage on voluntary feed intake in Experiment 1 (g/day, mean \pm SD).

\begin{tabular}{|c|c|c|c|c|c|}
\hline \multirow[t]{2}{*}{ Weeks } & \multicolumn{4}{|c|}{ Daily T-2 treatment (mg/animal)a } & \multirow[t]{2}{*}{$P$} \\
\hline & 0 & 0.05 & 0.10 & 0.20 & \\
\hline 1 & $155 \pm 39^{c}$ & $118 \pm 40^{\mathrm{bc}}$ & $98 \pm 32^{\mathrm{ab}}$ & $73 \pm 29^{a}$ & 0.000 \\
\hline 2 & $141 \pm 38^{b}$ & $98 \pm 32^{\mathrm{a}}$ & $93 \pm 45^{\mathrm{a}}$ & $77 \pm 25^{a}$ & 0.002 \\
\hline 3 & $139 \pm 39^{b}$ & $122 \pm 24^{\mathrm{ab}}$ & $111 \pm 35^{\mathrm{ab}}$ & $83 \pm 33^{a}$ & 0.005 \\
\hline 4 & $130 \pm 31$ & $121 \pm 11$ & $129 \pm 22$ & $101 \pm 30$ & 0.050 \\
\hline 5 & $125 \pm 21$ & $118 \pm 16$ & $123 \pm 33$ & $114 \pm 16$ & 0.687 \\
\hline 6 & $154 \pm 29$ & $140 \pm 16$ & $143 \pm 29$ & $140 \pm 28$ & 0.599 \\
\hline 7 & $151 \pm 34$ & $144 \pm 21$ & $152 \pm 22$ & $140 \pm 29$ & 0.739 \\
\hline 8 & $134 \pm 25$ & $117 \pm 14$ & $133 \pm 29$ & $130 \pm 30$ & 0.398 \\
\hline 9 & $128 \pm 18$ & $128 \pm 19$ & $133 \pm 21$ & $130 \pm 28$ & 0.952 \\
\hline
\end{tabular}

Different superscripts $(\mathrm{a}-\mathrm{c})$ in the same row indicate difference at $P<0.05$.

a $n=10$ in each group.

\subsection{Evaluation of semen quality}

The following spermatological parameters were evaluated: pH, concentration (improved Neubauer cell counting chamber), morphology and acrosomal integrity (Spermat $^{\mathrm{TM}}$ staining, Beernem, Belgium), as well as the total motility and fast/slow forward motility (Medealab ${ }^{\mathrm{TM}}$ CASA System, Erlangen, Germany) of spermatozoa. Motility analysis was carried out with CASA at a concentration of $80-120 \times 10^{6} / \mathrm{ml}$ after dilution of the semen with PBS. A minimum number of 200 spermatozoa were examined for morphology and 500 for motility evaluation (WHO, 1999). The concentration of seminal plasma components such as citric acid (Citric Acid Test, FertiPro, Belgium), zinc (Zinc, Wako Chemicals GmbH, Germany), fructose (Fructose Test, FertiPro, Belgium) were also measured (WHO, 1999).

\subsection{Determination of clinical chemical parameters}

The concentration of total protein, albumin, glucose, cholesterol, urea and creatinine, the activity of alkaline phosphatase, alanine aminotransferase, aspartate aminotransferase, gamma-glutamyl transferase were determined at the Central Laboratory of Kaposi Mór Teaching Hospital.

\subsection{Measurement of antioxidant parameters}

Antioxidant parameters were measured in blood plasma, red blood cell (1:9) hemolysate and seminal plasma. Glutathione peroxidase (GPx) activity was measured using reduced glutathione (GSH) and cumene hydroperoxide as co-substrates in an end-point direct assay following the system of (Lawrence and Burk, 1978). The loss of glutathione was measured using 5,5'-dithiobis 2 nitrobenzoic acid (Sedlak and Lindsay, 1968). The enzyme activity was expressed as nmol glutathione oxidation per minute at $25^{\circ} \mathrm{C}$. GPx activity was calculated to protein content, which was measured by the biuret method (Weichselbaum, 1948).

GSH content was determined based on the color complex formation of glutathione with 5,5'-dithiobis 2 nitrobenzoic acid (Sedlak and Lindsay, 1968).

Malondialdehyde (MDA) concentration was measured based on the color complex formation of malondialdehyde with 2-thiobarbituric acid in an acidic environment at high temperature (Placer et al., 1966).

\subsection{Histopathological examination of the testes}

The testes collected during the dissection of the tissues and were stored in $8 \%$ neutral buffered formaldehyde solution for histological examination, processed, sectioned (3-4 $\mu \mathrm{m})$ and stained with hematoxylin and eosin (HE).

\subsection{Determination of testosterone concentration}

The testosterone concentration was determined with a direct ${ }^{3} \mathrm{H}$-radioimmunoassay method (Csernus, 1982) adopted and validated for rodents' (chinchilla, rabbit and Angora rabbit) plasma (Kulcsar and Huszenicza, unpublished), described in details previously (Kovács et al., 2011).

\subsection{Statistical analyses}

Data were analyzed by using the Multiway ANOVA procedure of SPSS (2002), version 10.0. The significance of differences was tested by LSD post hoc test. GnRH-induced testosterone response was evaluated by comparing the modified area under the curve (modified AUC), meaning total AUC- ( $t 0$ value $\times 115 \mathrm{~min}$ ). A value of $P<0.05$ was considered as significant.

\section{Results}

\subsection{Experiment 1}

\subsubsection{Body weight, feed consumption and health}

No significant difference in body weight attributable to toxic effect was detected in any of the experimental animals (data not shown). None of the animals showed any clinical signs of toxicosis, and no animals died during the experiment.

In the first week T-2 in $0.1 \mathrm{mg}$ and 0.2 daily doses significantly decreased voluntary feed intake by $63 \%$ and $47 \%$, respectively, compared to controls (Table 1 ). In the second week the smallest dose $(0.05 \mathrm{mg} /$ animal/day) resulted in a temporary decreased feed consumption $(P<0.002)$, and in the 3rd week the feed refusal effect was detectable only with the largest dose $(0.2 \mathrm{mg} /$ animal/day, $P<0.005)$. 


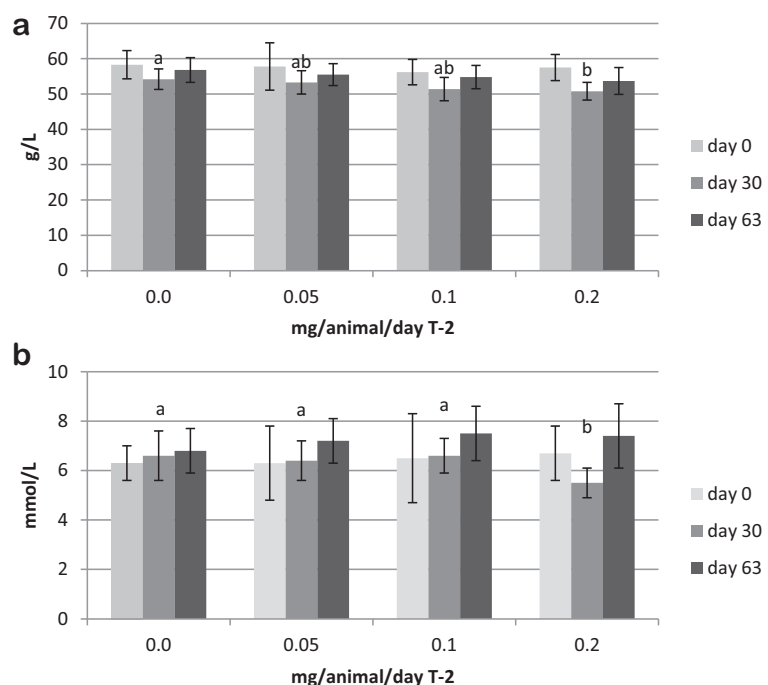

Fig. 1. Temporary decrease in albumin (Fig. 1a) and urea (Fig. 1b) concentration at the second sampling time (Day 30) in Experiment 1. Different superscripts $(\mathrm{a}$ and $\mathrm{b})$ indicate differences $(P<0.05)$ between treatments.

After the 2nd week, feed consumption began to increase in the toxin-treated animals, and no significant difference between groups was observed after the 4 th week.

\subsubsection{Clinical chemical parameters, antioxidant status}

None of the examined clinical chemical parameters showed significant differences due to toxin treatments, except for the temporary decreased albumin and urea concentrations observed on Day 30. On Day 30 the greatest $\mathrm{T}-2$ concentration resulted in a significantly lesser albumin concentration $(50.8 \pm 2.5 \mathrm{~g} / \mathrm{l})$ compared to the control group (54.2 $\pm 2.9 \mathrm{~g} / \mathrm{l}$, Fig. 1a), however, concentrations were consequently greater at every sampling time compared to the reference range (27-50 g/l; HarcourtBrown, 2002). Concentration of urea was significantly less for the $0.2 \mathrm{mg} \mathrm{T}-2$ treatment $(5.5 \pm 0.5)$ compared to the other three groups (6.4-6.6 g/l) on Day 30, and was less than the standard physiological range $(6.14-8.38 \mathrm{mmol} / \mathrm{l}$; Harcourt-Brown, 2002).

Antioxidant parameters did not change significantly in blood plasma and red blood cell hemolysates were not

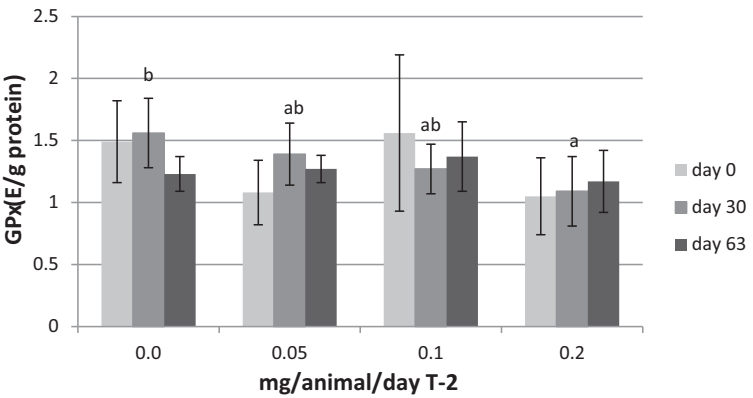

Fig. 2. Temporary decrease in glutathione peroxidase (GSH-Px) (expressed as nmol glutathione oxidation per minute at $25^{\circ} \mathrm{C}$, calculated to protein content) activity in the seminal plasma at the second sampling time (on day 30) in Experiment 1. Different superscripts (a and b) indicate differences $(P<0.05)$ between treatments.

impacted by treatment as assessed by the T- 2 challenge (data not shown). In seminal plasma, only GPx activity was significantly decreased on Day 30 as effected by the $0.2 \mathrm{mg} /$ animal/day T-2 treatment by gavage in Experiment 1, but this difference did not extend beyond Day 30 (Fig. 2).

\subsubsection{Sperm quality parameters}

None of the sperm quality parameters examined were significantly different between groups, except for the ratio of spermatozoa with cytoplasmic droplets, which increased by $320 \%$ in animals treated with the largest dose of T-2 (Table 2 ). On average $2.8 \%$ ( $\mathrm{SE}=0.76), 0.7 \%(\mathrm{SE}=0.2$ ), $4.5 \%(\mathrm{SE}=0.8), 13.3 \%(\mathrm{SE}=0.6)$ and $1.4 \%(\mathrm{SE}=0.96)$ of the sperm cells was microcephal, macrocephal, had broken or rolled tails, or lacked an acrosome, respectively. Despite the lack of statistical significance between groups in sperm motility, the trend of the data shows a negative toxin effect in case of this parameter (Table 2).

\subsubsection{Testosterone concentrations}

Basal testosterone concentration $(0 \mathrm{~min})$ was less by $30-50 \%$ in $0.2 \mathrm{mg} \mathrm{T}-2$ treated rabbits compared to the other three groups $(P>0.05)$ in Experiment 1. When comparing the GnRH induced hormone concentrations to the control animals, concentrations were less $(P>0.05)$ at $25 \mathrm{~min}$ in animals treated with 0.1 and $0.2 \mathrm{mg} \mathrm{T-2,} \mathrm{respec-}$ tively (Fig. 3). After $50 \mathrm{~min}$, in case of the largest dose ( $0.2 \mathrm{mg} / \mathrm{animal} / \mathrm{day})$ hormone concentration was less by

Table 2

Effect of T-2 toxin on certain sperm quality parameters in Experiment 1 (mean $\pm S D$ ).

\begin{tabular}{|c|c|c|c|c|c|}
\hline \multirow[t]{2}{*}{ Parameter } & \multicolumn{4}{|c|}{ Daily $\mathrm{T}-2$ treatment (mg/animal)a } & \multirow[t]{2}{*}{$P$} \\
\hline & 0 & 0.05 & 0.10 & 0.20 & \\
\hline Sperm cell count $\left(10^{6} / \mathrm{ml}\right)$ & $300 \pm 136$ & $345 \pm 359$ & $265 \pm 139$ & $277 \pm 111$ & 0.390 \\
\hline $\mathrm{pH}$ & $7.14 \pm 0.14$ & $7.23 \pm 0.27$ & $7.06 \pm 0.22$ & $7.09 \pm 0.16$ & 0.825 \\
\hline Citric acid (mg/ml) & $3.23 \pm 1.6$ & $4.06 \pm 1.86$ & $3.56 \pm 1.2$ & $3.51 \pm 1.79$ & 0.817 \\
\hline Fructose $(\mathrm{mg} / \mathrm{ml})$ & $1.43 \pm 0.7$ & $1.4 \pm 0.7$ & $1.2 \pm 0.7$ & $0.9 \pm 0.3$ & 0.559 \\
\hline $\mathrm{Zn}(\mu \mathrm{g} / \mathrm{ml})$ & $596 \pm 145$ & $686 \pm 115$ & $537 \pm 223$ & $675 \pm 207$ & 0.562 \\
\hline Normal morphology (\%) & $70 \pm 14$ & $69 \pm 19$ & $77 \pm 8$ & $70 \pm 7$ & 0.692 \\
\hline Retention of cytoplasmic droplets & $3^{a} \pm 0.6$ & $5.4^{\mathrm{ab}} \pm 2.0$ & $2.9^{\mathrm{a}} \pm 1.0$ & $9.6^{\mathrm{b}} \pm 2.4$ & 0.01 \\
\hline Motility & $85.4 \pm 5.5$ & $74.6 \pm 9.0$ & $72.9 \pm 18.1$ & $79.0 \pm 9.0$ & 0.133 \\
\hline Immotile cells & $11.4 \pm 5.0$ & $16.9 \pm 9.5$ & $25.1 \pm 7.8$ & $22.6 \pm 6.8$ & 0.072 \\
\hline
\end{tabular}

Different superscripts ( $a$ and $b$ ) in the same row indicate differences at $P<0.05$.

a $n=10$ in each group. 


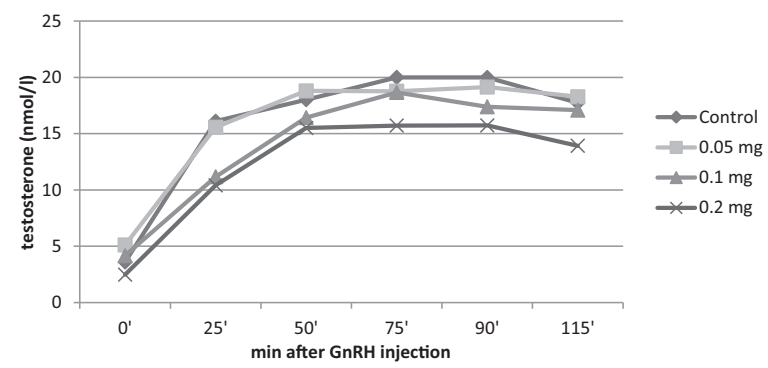

Fig. 3. Basal testosterone concentration and gonadotropin-releasing hormone $(\mathrm{GnRH})$ induced testosterone production in Experiment 1.

14\% $(P>0.05)$. Between 50 and $115 \mathrm{~min}$ the testosterone concentration in the $0.2 \mathrm{mg} \mathrm{T}-2$ treated animals was less by $21 \%$, while in case of 0.05 and $0.1 \mathrm{mg}$ toxin concentrations this difference did not exceed $10 \%$, compared to the controls $(P>0.05)$. When observing the rate of increase of testosterone concentration after GnRH injection, it was significantly $(P=0.02)$ less in the 0.1 and $0.2 \mathrm{~T}-2$ treated animals within the first $50 \mathrm{~min}$, i.e. these toxin exposures resulted in slower increase in the provoked hormone synthesis and/or release.

\subsubsection{Results of dissection and histopathology}

The liver showed mild regressive alteration and centro-lobular infiltration in one buck from the $0.05 \mathrm{mg} /$ animal/day-treated group, while in case of 0.1 and $0.2 \mathrm{mg} / \mathrm{animal} /$ day treated group, three animals in both groups had these alterations. However, this adverse effect was not supported by the measured liver enzyme activities (see above).

Weight of the testes were between $10.4 \pm 1.7$ and $11.1 \pm 2.0 \mathrm{~g}$, without significant differences between groups $(P=0.852)$. Other organs examined (liver, spleen and kidneys) also did not show any difference in weight (data not shown).

According to the histological examinations, control animals and those treated with $0.05 \mathrm{mg} / \mathrm{animal} / \mathrm{day} \mathrm{T}$ 2 had active testes, physiological spermatogenesis and intact parenchyma. Daily $0.1 \mathrm{mg} /$ animal $\mathrm{T}-2$ resulted in a slight hyperplasia of the Leydig cells, while the largest dose $(0.2 \mathrm{mg} / \mathrm{animal} / \mathrm{day})$ caused increased proliferative activity of the Leydig cells and the testes were slightly hyperaemic.

\subsection{Experiment 2}

According to the results of the first experiment the NOAEL of T-2 in adult bucks was found to be between 0.05 and $0.1 \mathrm{mg} / \mathrm{animal} /$ day (i.e. $0.01-0.02 \mathrm{mg} / \mathrm{kg}$ b.w./day). Because $\mathrm{T}-2$ toxin was provided by gavaging the animals, the question arose if rabbits would consume freely a diet containing the same amount of toxin. Therefore, in the second experiment the voluntary feed intake of rabbit bucks was measured after contaminating the diet with 0.33 and $0.66 \mathrm{mg} / \mathrm{kg} \mathrm{T}-2$ (provided in fungal culture). After 65 days of toxin treatment, the main sperm quality parameters and testosterone concentrations were determined.
Table 3

Effect of in feed T-2 exposure on voluntary feed intake in Experiment 2 $(\mathrm{g} /$ day, mean $\pm \mathrm{SD})$.

\begin{tabular}{lcrrr}
\hline Weeks & \multicolumn{2}{l}{ T-2 treatment $(\mathrm{mg} / \text { feed })^{\mathrm{a}}$} & \multirow{2}{*}{$P$} \\
\cline { 2 - 4 } & 0 (control) & \multicolumn{1}{c}{0.33} & \multicolumn{1}{c}{0.66} & \\
\hline 1 & $123 \pm 40$ & $130 \pm 41$ & $157 \pm 23$ & 0.118 \\
2 & $116 \pm 24$ & $107 \pm 24$ & $129 \pm 16$ & 0.125 \\
3 & $149 \pm 19$ & $130 \pm 37$ & $153 \pm 16$ & 0.183 \\
4 & $92 \pm 19$ & $85 \pm 28$ & $96 \pm 14$ & 0.601 \\
5 & $132 \pm 8$ & $104 \pm 28$ & $129 \pm 26$ & 0.092 \\
7 & $146 \pm 20$ & $137 \pm 33$ & $151 \pm 24$ & 0.550 \\
9 & $108 \pm 18$ & $106 \pm 21$ & $120 \pm 16$ & 0.269 \\
\hline a $n=10$ in each group. & & &
\end{tabular}

\subsubsection{Body weight, feed consumption and health}

No significant difference in body weight attributable to a toxic effect of treatment was detected (data not shown). None of the animals showed any clinical signs of toxicosis, and there was no mortality during the experiment. Feeding the contaminated diets did not cause feed refusal (Table 3). However, there was temporary fluctuation in the feed intake in all groups, but irrespective of the diet consumed.

\subsubsection{Sperm quality parameters}

None of the sperm quality parameters determined indicated a treatment effect (Table 4). The ratio of cells showing retention of cytoplasmic droplets was greater by $50 \%$ and $33 \%$ in case of $0.66 \mathrm{mg} / \mathrm{kg}$ feed T-2 as compared to 0 and $0.33 \mathrm{mg} / \mathrm{kg}$ groups, respectively, but the difference was not significant.

\subsubsection{Testosterone concentrations}

Basal testosterone concentration was 36\% and 38\% less in T-2 challenged animals, compared to controls, however, the differences were not significant (Fig. 4). Within 25 and 110 min plasma testosterone concentration in treated rabbits was less by $5-21 \%$, but differences were inconsequent and statistically not different.

\section{Discussion}

The T-2 toxin dose applied in the present study to male rabbits was $0.01,0.02$ or $0.05 \mathrm{mg} / \mathrm{kg}$ b.w./day, which represents about $0.3,0.6$ or $1.3 \mathrm{mg} / \mathrm{kg}$ feed contamination. The $0.3 \mathrm{mg} / \mathrm{kg}$ feed can be considered as a risk under practical

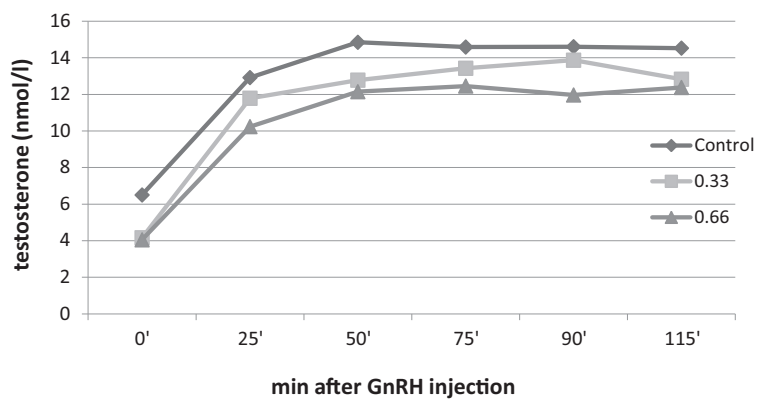

Fig. 4. Basal testosterone concentration and gonadotropin-releasing hormone (GnRH) induced testosterone production in Experiment 2. 
Table 4

Sperm quality parameters in Experiment 2 (mean \pm SD).

\begin{tabular}{|c|c|c|c|c|}
\hline \multirow[t]{2}{*}{ Weeks } & \multicolumn{3}{|c|}{$\mathrm{T}-2$ treatment (mg/feed $)^{\mathrm{a}}$} & \multirow[t]{2}{*}{$P$} \\
\hline & 0 (control) & 0.33 & 0.66 & \\
\hline Sperm cell count $(106 / \mathrm{ml})$ & $213 \pm 102$ & $244 \pm 167$ & $211 \pm 88$ & 0.822 \\
\hline Normal morphology (\%) & $77 \pm 12$ & $75 \pm 9$ & $77 \pm 10$ & 0.883 \\
\hline Retention of cytoplasmic droplets (\%) & $3 \pm 2$ & $4 \pm 1.7$ & $6 \pm 3.4$ & 0.639 \\
\hline Motility (\%) & $70 \pm 8$ & $70 \pm 4$ & $68 \pm 15$ & 0.884 \\
\hline Citric acid (mg/ml) & $2.0 \pm 0.9$ & $3.3 \pm 1.5$ & $2.1 \pm 1.3$ & 0.083 \\
\hline Fructose $(\mathrm{mg} / \mathrm{ml})$ & $1.7 \pm 0.6$ & $2.1 \pm 0.8$ & $1.8 \pm 0.6$ & 0.653 \\
\hline Zinc $(\mu \mathrm{g} / \mathrm{dl})$ & $672 \pm 97$ & $601 \pm 100$ & $647 \pm 159$ & 0.511 \\
\hline
\end{tabular}

a $n=10$ in each group.

conditions, as approximately $5 \%$ of examined feed samples (including rabbit feed) in Hungary contained $0.1-0.5 \mathrm{mg} / \mathrm{kg}$ T-2 as the average of the last 5 years (unpublished data).

Trichothecenes are shown to alter the serotoninergic neuronal activity in the central nervous system. Serotoninergic receptors are important mediators in appetite regulation, so an increased serotonin concentration may be the reason of the decreased appetite (Smith, 1992). The least toxin concentration in the scientific literature which did not cause the feed refusal phenomenon of T2 was $0.01 \mathrm{mg} / \mathrm{kg}$ b.w. in rabbits (Fekete and Huszenicza, 1993). This has been previously reported, as $0.01 \mathrm{mg} / \mathrm{kg}$ b.w. $(0.05 \mathrm{mg} /$ animal $) \mathrm{T}-2$ resulted in a short temporary decrease in feed intake, experienced only in the 2nd week compared to the 1st week's data. Even in case of larger doses, feed intake returned to normal values within 4 weeks indicating the adaptation of the animals to the toxin with regard to feed intake.

The health status of the animals can be monitored by regular determination of certain clinical chemical parameters. The liver is considered to be the primary target organ of many mycotoxins, and of trichothecenes in all species examined. Hypo-albuminemia is a feature of advanced liver diseases in all species. Laboratory reference ranges for serum albumin concentrations in rabbits can be wide and vary between sources. A greater serum albumin, as observed in this experiment, is not a feature of any specific disease, diet and husbandry may influence concentraions of this protein in blood (Harcourt-Brown, 2002). Results of the present study showed that T-2 in the greatest dose $(0.05 \mathrm{mg} / \mathrm{kg}$ b.w./day) resulted in temporary hepatic dysfunction, as indicated by the decreased albumin and urea concentrations on Day 30. As total protein was not affected, hypo-albuminemia was probably not the result of the direct protein synthesis inhibiting effect, but rather the hepatotoxic effect of $\mathrm{T}-2$, causing parenchymal damage in the liver. This was supported by the mild regressive alteration, centrolobular infiltration of the liver, in one animal in the group treated with $0.05 \mathrm{mg} / \mathrm{animal} / \mathrm{day}$, and three animals in both groups treated with 0.1 or $0.2 \mathrm{mg} / \mathrm{animal} / \mathrm{day}$ at the end of the experiment. Low blood urea concentrations can also reflect hepatic dysfunction (Harcourt-Brown, 2002). However, urea metabolism of rabbits is complicated by the caecal microbial urea utilization, so small fluctuations in plasma urea concentrations are difficult to interpret. Edrington et al. (1997) also reported decreased serum urea nitrogen concentrations when feeding growing broilers with a diet containing $6 \mathrm{mg} / \mathrm{kg} \mathrm{T}-2$.
Antioxidant parameters did not change significantly as effected by T-2 challenge, except for moderate decreases of GPx activity in seminal plasma on Day 30 with the largest dose. These results mean that the biological antioxidant system was able to eliminate the potential free radical generation effect of T-2 in rabbits. This is supported by Guerre et al. (2000) who found that a daily dose up to $0.10 \mathrm{mg} / \mathrm{kg}$ b.w. T-2 did not result in oxidative damage in rabbits.

One of the main goals with the present study was to detect reproductive toxic effects of T- 2 in males. The length of the toxin treatment was 64 days. The cycle of the seminiferous epithelium lasts 10.7 days in rabbits. In sub-chronic toxicity studies it has been recommended to expose the animals to the test compound for at least six cycles of the epithelium before the effect is evaluated (Amann, 1982). In rabbits, this would require 64 days. This period is enough for the agent to accumulate in tissues, exert its effect, and produce changes in the sperm in the ejaculate, and cause histological lesions.

Among the parameters used for evaluation of sperm quality in the present study only the ratio of spermatozoa with retention of cytoplasmic droplets differed $(P=0.01)$ in the animals treated with the largest toxin dose $(0.05 \mathrm{mg} / \mathrm{kg}$ b.w./day). This may be the result of the impaired epididymal function, i.e. maturation of spermatozoa (Parkinson, 2009; Yeung, 1995). This could also lead to decreased spermatozoa motility (more immotile cells) in the toxin-treated groups (though differences were not significant). The male reproductive organs are strongly androgen-dependent in respect of structure as well as function. Testosterone supports spermatogenesis, sperm maturation, seminal plasma production and sexual functions (De Kretser and Kerr, 1994). The disruption of testosterone biosynthesis in Leydig cells can adversely affect male fertility (Parkinson, 2009; Weinbauer et al., 2000). In the present experiment, basal testosterone concentration was less by $30-50 \%$ in $0.2 \mathrm{mg}$ T-2 treated rabbits compared to the other three groups (not significant), and after GnRH injection, increases in the testosterone concentration was significantly less in the 0.1 and $0.2 \mathrm{~T}-2$ treated animals within the first $50 \mathrm{~min}$. Nikodémusz and Mézes (1992) also observed significantly less testosterone production after $\mathrm{GnRH}$ induction in ganders treated with a small dose of T-2. T-2 may decrease the testosterone production of the Leydig cells by inhibiting early steps of the steroidogenic pathway, i.e. the conversion of pregnenolone to progesterone (Fenske and Fink-Gremmels, 
1990). T-2 may act indirectly as well, on the pituitary gland, or affect sertoli cell inhibin production as has been shown with another trichothecene mycotoxin, deoxynivalenol (Sprando et al., 2005). The direct effect of the toxin on Leydig cells is more feasible, supported by histopathological hyperplasia of the cells.

All sperm quality problems previously described were observed with the two larger doses (0.1 and $0.3 \mathrm{mg} / \mathrm{animal} /$ day) and only when applied as pure toxin by gavage in the present research. If the same amount of T-2 was applied in feed, no significant adverse effect of the toxin was observed. Although in rabbits fed with a diet containing $0.66 \mathrm{mg} / \mathrm{kg} \mathrm{T}-2$ more sperm cells with retention of cytoplasmic droplets were found and a slower increase in testosterone concentration after GnRH injection was observed. However, these differences were not statistically significant. An explanation for the lack of alterations can be the different absorption rate and toxicokinetic properties of purified T-2 solubilized in ethanol:water (2:98) solvent compared to its native form in the fungal culture. The lipophilic nature of trichothecene toxins suggests that they are easily absorbed. Radioactivity peaked in plasma of mice 30 min after oral administration of $\left[{ }^{3} \mathrm{H}\right]$ T-2 toxin. Single oral administration of 0.5 or $1 \mathrm{mg} / \mathrm{kg} \mathrm{T}$ 2 in diets of chickens resulted in a 60-65\% absorption within $120 \mathrm{~min}$ (Schuhmacher-Wolz et al., 2010). The mode of toxin administration, i.e. the feed matrix might influence absorption, as previously theorized (Eriksen, 2003) that an intra-gastric administered dose of another trichothecene mycotoxin, deoxynivalenol, might be more available for absorption than toxin mixed into the feed. This phenomenon, i.e. mycotoxins in naturally contaminated food are complexed to the food matrix, has been previously described by Meca et al. (2012a). The amount of macroand micro-nutrients influences the formation of these complexes. Different bioavailability was reported (Meca et al., 2012b), comparing the same compounds contained in liquid or solid food. No data are available concerning the transport mechanism of T-2 across the intestinal epithelial cells and factors influencing this mechanism.

Summarizing results of the present study, it may be concluded that the NOAEL for adult male rabbits is $<0.1 \mathrm{mg} /$ animal/day ( $<0.02 \mathrm{mg} / \mathrm{kg} \mathrm{b.w}$./day), which is about one order of magnitude less than identified for other rodents (mice and rats), and less than the least NOAEL, which is $0.03 \mathrm{mg} / \mathrm{kg}$ b.w./day as observed in the short term toxicity study on pigs (SCF, 2001). This is in accordance with the observations of Wannemacher and Wiener (1997), who considered rabbits as sensitive to T-2 toxin, having a relatively low (1.1 mg/kg b.w.) LD $_{50}$ value. Caecotrophy, by which substantial toxin quantities get back into the digestive tract so resulting in prolonged excretion times, may have a role in rabbits' greater sensitivity to toxic substances (Ványi et al., 1988).

\section{Conclusions}

Adult male rabbits may tolerate the feed concentration of 0.33 or $0.66 \mathrm{mg} / \mathrm{kg}$ ( 0.05 or $0.1 \mathrm{mg} / \mathrm{animal} /$ day) $\mathrm{T}-2$ toxin, without any significant decay in sperm quality, though $0.1 \mathrm{mg} / \mathrm{animal} / \mathrm{day}$ toxin caused a slight alteration in the Leydig cells. Greater doses of T-2 toxin ( $0.2 \mathrm{mg} /$ animal/day) had a more pronounced feed refusal effect, caused temporary decrease in the plasma albumin and urea concentration and GPx activity of the seminal plasma, dramatically increased the ratio of spermatozoa with cytoplasmic droplets, caused hyperaemia in the testes and hyperplasia in the Leydig cells. According to these results the No Observed Adverse Effect Level (NOAEL) for adult rabbit males is found to be $<0.1 \mathrm{mg} /$ animal/day (<0.02 mg/kg b.w./day).

\section{Acknowledgments}

This research was supported by the Office for Subsidised Research Units of the Hungarian Academy of Sciences (project no.: 13003) and the TÁMOP 4.2.2.A-11/1/KONV2012-0053 project. We are grateful to Dr. Zsolt Gerencsér, András Bónai and Bence Somoskői in their participation in the experiment and also to Zsuzsanna Keresztes for her laboratory work performing sperm quality measurements. Acknowledgements to the Central Laboratory of Kaposi Mór Teaching Hospital for the determination of clinical chemical parameters.

\section{References}

Alm, K., Dahlbom, M., Säynäjärvi, M., Andersson, M.A., Salkinoja-Salonen, M.S., Andersson, M.C., 2002. Impaired semen quality of AI bulls fed with moldy hay: a case report. Theriogenology 58, 1497-1502.

Amann, R.P., 1982. Use of animal models for detecting specific alterations in reproduction. Fundam. Appl. Toxicol. 2, 13-26.

Csernus, V., 1982. Antibodies of high affinity and specificity for RIA determination of progesterone, testosterone, estradiol-17 $\beta$ and cortisol In: Görög, G. (Ed.), Advances in Steroid Analysis. I. Academic Press, Budapest, Hungary, pp. 171-177.

De Kretser, D.M., Kerr, J.B., 1994. The cytology of testis. In: Knobil, E., Neill, J.D. (Eds.), The Physiology of Reproduction. Raven Press Ltd., New York, pp. 1117-1290.

Edrington, T.S., Kubena, L.F., Harvey, R.B., 1997. Influence of a superactivated charcoal on the toxic effects of aflatoxin or T-2 toxin in growing broilers. Poult. Sci. 76, 1205-1211.

Eriksen, G.S., 2003. Metabolism and toxicity of trichothecenes. Ph.D. Thesis. Swedish University of Agricultural Sciences, Uppsala, Sweden.

Fekete, S., Huszenicza, G.Y., 1993. Effects of T-2 toxin on ovarian activity and some metabolic variables of rabbits. Lab. Anim. Sci. 43, 646-649.

Fenske, M., Fink-Gremmels, J., 1990. Effect of fungal metabolites on testosterone secretion in vitro. Arch. Toxicol. 64, 72-75.

Fodor, J., Németh, M., Kametler, L., Pósa, R., Kovács, M., Horn, P., 2006. Novel methods of Fusarium toxins' production for toxicological experiments. Methodological study. Acta Agraria Kaposvariensis 10, 277-285.

Foote, R.H., Carney, E.W., 2000. The rabbit as a model for reproductive and developmental toxicity studies. Reprod. Toxicol. 14, 477-493.

Guerre, P., Eeckhoutte, C., Burgat, V., Galtier, P., 2000. The effects of T-2 toxin exposure on liver drug metabolizing enzymes in rabbit. Food Addit. Contam. 17, 1019-1026.

Harcourt-Brown, F., 2002. Textbook of Rabbit Medicine. Elsevier, Oxford, Grait Britain.

Kovács, M., Tornyos, G., Matics, Z., Kametler, L., Rajli, V., Bodnár, Z., Kulcsár, M., Huszenicza, G., Keresztes, Z., Cseh, S., 2011. Subsequent effect of subacute T-2 toxicosis on spermatozoa, seminal plasma and testosterone production in rabbits. Animal 10, 1563-1569.

Lawrence, R.A., Burk, R.F., 1978. Species, tissues and subcellular distribution of non-selenium dependent glutathione peroxidase activity. J. Nutr. 108, 211-215.

Meca, G., Meneghelli, G., Ritieni, A., Manes, J., Font, G., 2012a. Influence of different soluble dietary fibres on the bioaccessibility of the minor Fusarium mycotoxin beauvericin. Food Chem. Toxicol. 50, 1362-1368.

Meca, G., Manes, J., Font, G., Ruiz, M.J., 2012b. Study of the potential toxicity of commercial crispy breads by evaluation of bioaccessibility and bioavailability of minor Fusarium mycotoxins. Food Chem. Toxicol. 50, 288-294. 
Morton, D., 1988. The use of rabbits in male reproductive toxicology. Environ. Health Perspect. 77, 5-9.

Nikodémusz, E., Mézes, M., 1992. Subchronic toxic effects of dietary T2 toxin in breeding geese. In: Proc. 9th International Symposium on Water Fowl, Pisa, pp. 201-203.

Parkinson, T., 2009. Normal reproduction in male animals. In: Noakes, D.E., Parkinson, T.J., England, G.C.W. (Eds.), Veterinary Reproduction and Obstetrics. Saunders Elsevier, London, pp. 681-705.

Placer, Z.A., Cushman, L.L., Johnson, B.C., 1966. Estimation of product of lipid peroxidation (malonyl dialdehyde) in biochemical systems. Anal. Biochem. 16, 359-364.

Schuhmacher-Wolz, U., Heine, K., Schneider, K., 2010. Report on toxicity data on trichothecene mycotoxins HT-2 and T-2 toxins. CT/EFSA/CONTAM/2010/03, Question No EFSA-Q-2010-0143, http://www.efsa.europa.eu/en/scdocs/doc/65e.pdf

Scientific Committee on Food (SCF), 2001. Opinion of the Scientific Committee on Food on Fusarium Toxins. Part 5: T-2 Toxin and HT-2 Toxin. European Commission, Brussels, Belgium http://ec.europa.eu/food/fs/sc/scf/out88_en.pdf

Scott, P.M., 1990. Trichothecenes in grains. Cereal Food World 35 , 661-666.

Sedlak, I., Lindsay, R.H., 1968. Estimation of total, protein-bound and nonprotein sulfhydryl groups in tissues with Ellmann's reagent. Anal. Biochem. 25, 192-205.

Smith, T.K., 1992. Recent advances in the understanding of Fusarium trichothecene mycotoxicoses. J. Anim. Sci. 70, 3989-3993.

Sprando, R.L., Collins, T.F.X., Black, T.N., Olejnik, N., Rorie, J.I., Eppley, R.M., Ruggles, D.I., 2005. Characterization of the effect of deoxynivalenol on selected male reproductive endpoints. Food Chem. Toxicol. 43, 623-635.

Van der Fels-Klerx, H.J., Stratakou, I., 2010. T-2 toxin and HT-2 toxin in grain and grain-based commodities in Europe: occurrence, factors effecting occurrence, co-occurrence and toxicological effects. World Mycotoxin J. 3, 349-367.

Ványi, A., Bata, Á., Fekete, S., Tamás, J., 1988. Study on the metabolism and excretion of T-2 toxin, a trichothecene fusariotoxin, in rabbits. Acta Vet. Hung. 36, 213-220.

Wannemacher, R.W., Wiener, S.L., 1997. Trichothecene mycotoxins. In: Zajtchuk, R. (Ed.), Medical Aspects of Chemical and Biological Wearforce. Textbook of Military Medicine. Burden Institute, Washington, DC, pp. 655-677.

Weichselbaum, T.E., 1948. An accurate and rapid method for the determination of protein in small amounts of serum and plasma. Am. J. Clin. Pathol. 16, 40-43.

Weinbauer, G.F., Gromoll, J., Simoni, M., Nieschlag, E., 2000. Physiology of testicular function. In: Nieschlag, E., Behre, H.M. (Eds.), Andrology. Male Reproductive Health and Dysfunction. Springer, Berlin, pp. 23-63.

WHO (World Health Organisation), 1999. WHO Laboratory Manual for the Examination of Human Semen and Sperm-Cervical Mucus Interaction. WHO, 4th ed. Cambridge University Press, UK, p.138.

WHO (World Health Organization), 2001. Food Additives Series: 47. Safety evaluation of certain mycotoxins in food. Prepared by the Fifty-Sixth Meeting of the Joint FAO/WHO Expert Committee on Food Additives (JECFA). http://www.inchem.org/documents/ jecfa/jecmono/v47je01.htm

Yang, J.Y., Zhang, Y.F., Liang, A.M., Kong, X.F., Li, Y.X., Ma, K.W., Jing, A.H., Feng, S.Y., Qiao, X.L., 2010. Toxic effects of T-2 toxin on reproductive system in male mice. Toxicol. Ind. Health 26, 25-31.

Yeung, C.H., 1995. Development of sperm motility. In: Hamanah, S., Mieusset, R., Dacheux, J.L. (Eds.), Frontiers in Endocrinology. Epididymis: Role and Importance in the Infertility Treatment. Ares Serono Symposia. Rome, pp. 73-86. 